\title{
Perkembangan Ilmu Hukum dalam Perspektif Perkembangan Sains Global
}

\author{
Zudan Arif Fakrulloh
}

\begin{abstract}
Abstrak
The impact of global science on the development of legal science has been the normative reduction or positivization of law. This leads to strengthening the normative image of law, narrowing the appearance of law, sparating law from the social facts, etc. These imply that a new theory capable of deliberating of law from its normative of image is such urgent that the theory is capable of describing the truth about law. Therefore, Critical Legal Studies should be given a conducive room to develop in order to enlighten the legal science.
\end{abstract}

\section{Pendahuluan}

Jauh sebelum Alvin Toffler mengedepankan konsep globalisasi yang di dalamnya berisi skenario tentang perkembangan ilmu dan teknologi, di dalam bidang ilmu pengetahuan telah tejadi "globalisasi" yang bermakna sebagai keterpengaruhan. Dalam bidang hukum, sudah terjadi keterpengaruhan dan persinggungan di antara sistem hukum yang ada. Baik sistem hukum Anglo Saxon, Kontinental, Sosialis maupun Sistem Hukum Timur Tengah dan Timur Jauh, tidak lagi berdiri sebagai sistem hukum yang otonom dan terlepas dari yang lainnya. Tidak ada lagi sebuah negara yang mengklaim menganut salah satu sistem hukum tersebut secara absolut. Adanya project ELLIPS, merupakan salah satu fakta adanya upaya untuk memasukan pengaruh unsur-unsur dalam sistem anglo saxon ke dalam sistem Kontinental yang diyakini oleh Indonesia.

Apabila dianalogikan, ' perkembangan ilmu pengetahuan dapat dibaratkan sebagai susunan batu bata yang membentuk sebuah bangunan. Batu-bata yang terpasang kemudian (di atasnya), mestilah merekat pada batu-bata di bawahnya, demikian seterusnya

'Bagan mengenai aspek ragam dikembangkan oleh Marius Stafleu yang berasal dari pemikiran Herman Doojewerd. Pemahaman terhadap aspek ragam yang terdiri dari aspek ragam numeris, spesial, kinematik, fisis, biotik, psikis, sosial budaya dilakukan melalui proses analogi antisipasi (melihat aspek ragam yang lebih tinggi) maupun restrosipasi (melihat ke aspek ragam yang lebih rendah) MD Stafleu. 1980.Time and Again. 
sampai menjadi sebuah bangunan. Proses perkembangan ilmu sebagaimana dikatakan oleh Karl Popper tidaklah dimulai dari sesuatu yang nihil/kosong, tetapi perkembangan ilmu pengetahuan tersebut mendasarkan pada pengetahuan yang lebih dahulu ada. Proses ini oleh Hegel disebut sebagai Dialektika yang diawali dengan tesa kemudian sintesa dan menghasilkan tesa baru yang disebut sebagai antitesa. Sedangkan Bergson ${ }^{2}$ menyebutnya sebagai evolusi yang kreatif (creative evolution). Dengan memberikan perhatian pada aspek destruksi yang konstruktif ${ }^{3}$, Thomas Kuhn menyebutnya proses itu sebagai Scientific Revolution, sedangkan Karl Popper dengan titik berat pada aspek testabilitas yang ketat, proses itu disebutnya sebagai proses penyingkiran kesalahan (falsifikasi) ${ }^{4}$

Dalam makalah ini penulis hendak menukikkan persoalan pada pengaruh sains global terhadap perkembangan ilmu hukum. $\mathrm{Pe}-$ nulisan makalah yang cenderung sangat abstrak ini yang sebisa mungkin akan penulis arahkan pada aspek konseptual didasarkan oleh pemikiran sebagai berikut: pertama, tidak banyak ahli hukum yang memberikan perhatian pada masalah-masalah hukum yang bersifat konseptual. Bagian terbesar dari ahli hukum cenderung memberikan perhatian yang lebih besar pada sisi praksis-pragmatis. Persoalan ini terjadi karena adanya desakan kebutuhan. Hal ini merupakan akibat langsung dari kesenjangan yang disebabkan terbatasnya ahli hukum dengan persoalan praktis dalam hubungan bisnis yang semakin global maupun dalam kehidupan sehari-hari yang masih sederhana sifatnya. Kedua, di antara para ahli yang menaruh perhatian pada hal yang konseptual ini, masih terdapat perbedaan yang mendasar tentang persepsi hukum sebagai sistem atau nonsistem. ${ }^{5}$ Masalah yang kedua ini terjadi karena adanya pengaruh

\footnotetext{
${ }^{2}$ Bergson menyebut evolusi yang kreatif adalah pertumbuhan ilmu sebagai suatu proses koreksi yang berkesinambungan yang menghubungkan masa lalu dengan masa kini dari mana suatu gejala kekinian dapat dipahami melalui pemahaman terhadap gejala yang mendahuluinya. Saxe Commins and Robert N Linscolt. 1954. The Philosophers of Science. Him. 278.

${ }^{3} T h o m a s$ Kuhn. 1989. Peranan Paradigma dalam Revolusi Sains. HIm. 72.

${ }^{4}$ Alvons Taryadi: 1989. Epistemologi Pemecahan Masalah Menurut Karl. R. Popper. HIm. 140. Lihat juga Thomas Kuhn. Op. Cit. HIm. 157.

5Sebagian besar ahli hukum meyakini bahwa hukum sebagai sistem, misalnya Soepomo dalam karyanya yang berjudul Sistem Hukum (1977), Sunaryati Hartono memahami sistem hukum sebagai sesuatu yang terdin dari sejumlah unsur yang terkait satu sama lain (1991:56), Lili Rasjidi dalam bukunya Hukum sebagai Sistem (1993:104) mengartikan sistem hukum sebagai satu kesatuan sistem besar yang tersusun atas subsistem yang lebih kecil yaitu subsistem pendidikan, pembentukan hukum, penerapan hukum, budaya hukum, masyarakat hukum dan lain-lain yang pada hakekatnya merupakan sistem tersendiri dengan proses lersendiri pula, Prof. Satjipto Rahardjo, ketika membicarakan "model Sistemik Administrasi Pengadilan" (1983:35) menekankan pentingnya pendekatan sistem yang bertolak dari kepentingan terdakwa dari efisiensi administrasi. Tokoh yang lain seperti Hart, Raz, Harris, Parson, memandang hukum sebagai sistem. Pandangan-pandangan di atas mendapat bandingan atau bahkan kritik keras dari Charles Sampford yang secara tegas mengatakan bahwa "despite is orthodoxy of the view that law forms a system, what is meant by clear or uniform (1989:13), yang kemudian lebih ditekankan lagi oleh Samford bahwa suatu masyarakat tempathidup dari hukum itu adalah "as essentially discordered and unsystimatic" (1989:149).
} 
sains global terhadap perkembangan ilmu hukum dan pengaruh perbedaan pemikiran yang berkembang dalam aliran-aliran ilmu hukum yang berkembang bersamaan dengan sains global. Masalah ketiga berasal dari faktor internal dan eksternal. Masalah internal yang terjadi adalah merupakan kelanjutan dari perbedaan pemikiran hukum yang bersifat sektoral yang masih berkembang dan berrlanjut terus dalam ilmu hukum. Masalah ini juga didukung oleh kondisi eksternal yaitu besarnya intervensi cabang-cabang ilmu lain terhadap ilmu hukum. Saat ini hukum tidak saja menjadi objek dari ilmu hukum, melainkan juga diakui sebagai objek ilmu sosial (Sosiologi Hukum), Antropologi maupun ilmu politik. Masalah ekstemal lainnya adalah adanya heterogenitas kondisi sosial budaya masyarakat yang mempunyai ciri khas berbeda satu dengan yang lain, termasuk di dalamnya adalah tingkat pendidikan dan tingkat sosial ekonomi yang tidak merata. ${ }^{6}$

\section{Pengaruh Perkembangan Sains Global Terhadap Perkembangan IImu Hukum}

Pertengahan Abad ke-20 merupakan periode yang penting bagi perkembangan filsafat ilmu dan sains ${ }^{7}$ modern. Periode ini ditandai dengan bangkitnya kesadaran manusia ter- hadap kelemahan yàng terkandung dalam formulasi sains modem.

Formulasi sains modern yang dibangun di atas logika murni oleh Rene' Descartes telah membawa akibat buruk yang luas ke alam dimensi ontologi, aksiologi dan epistemologi ilmu pengetahuan. Menurut logika Cartes (Cartesian) pengertian ilmu hanyalah terbatas pada cabang-cabang ilmu pengetahuan yang tidak berobjek benda-benda alam dan tidak menggunakan metoda eksperimental dianggap bukan sains. Penegasan ontologi ilmu pengetahuan dilakukan dengan menggunàkan batasan metoda eksperimental.

Akibat menonjolnya pengaruh filsafat Cartesian ini adalah mengaburnya status ilmiah' cabang-cabang ilmu pengetahuan yang tidak berontologi benda alam, seperti ilmu sosial; ilmu hukum, ilmu kebudayaan dan ilmu yang berobjek manusia (human sciences) lainnya. Pengaruh ini ternyata berimbas pula kedalam perilaku para ahli ilmu alam yang menganggap bahwa sains di luar ilmu alam adalah tidak' ilmiah. Sikap ini berjalan seiring dengan sikap yang mengkultuskan metode eksperimental dan benda alam sebagai, objek ilmu pengetahuan yang sudah berkembang sejak abad ke-16. Hakekat objektivitas kebenaran sains mereka tempatkan pada dapat tidaknya suatu objek diuji secara eksperimental, bukan

${ }^{6}$ Made Widnyana. Ed. 1995. Bunga Rampai Pembangunan Hukum Indonesia. HIm. 253-254.

'Secara etimologis, kata sains berasal dari science yang berarti ilmu pengatahuan. Untuk memperoleh takrif sains yang tepat dapat digunakan rumus Terminus definiendum=genus proxium + diferencia spesificia (lihat Like Wilardjo. 1990. Realita dan Desiderata. 26). Jadi istilah sains dan ilmu pengetahuan adalah pengetahuan (knowledge) yang memiliki karakter keilmuan (scientific). Taktifini dapat dipertuas dengan berbagai cara sesuai dengan disiplin ilmu yang menerbitkan takrif tersebut. Secara umum ilmu sering ditakrifkan sebagai pengetahuan yang tersusun secara sistematis, objektif dan metodologis atau secara filosofis, ilmu dianggap sebagai pengetahuan yang memenuhi syarat-syarat ontologi, epistemologi dan aksiologi. 
pada ukuran seberapa banyak suatu metoda mampu mengungkap kelengkapan karakteristik objek.

Menghadapi sikap para ahli ilmu alam yang cenderung mengagungkan bidang ilmunya, di kalangan ahli ilmu sosial dan kemanusiaan timbul reaksi untuk membuktikan sifat saintifik bidang ilmunya. Reaksi yang muncul ini dapat dikatagorikan ke dalam dua bagian yaitu mereka yang membuktikan sifat saintifik ilmu sosial dengan menggunakan metodametoda yang sesuai dengan objek cabang ilmu sosial dan mereka yang membuktikan dengan cara menerapkan metoda ilmu alam ke dalam ilmu sosial dan kemanusiaan. ${ }^{8}$ Cara yang kedua ini meluas ke hampir semua cabang ilmu sosial dan kemanusiaan. Walaupun secara absolut tidak salah, namun cara pendekatan dengan menggunakan metodà ilmu alam ke dalam ilmu sosial ini cenderung mengaburkan sifat atau keutuhan karakteristik manusia, yang akhimya cenderung memekanismekan manusia. ${ }^{9}$

Ilmu hukum sebagai bagian dari sains global tidak dapat melepaskan diri dari pengaruh perkembangan di atas. Pengaruh yang menonjol dari proses perkembangan sains global adalah terjadinya dominasi pendekatan mekanistis analitis dalam epistemologi ilmu hukum, yang berakibat menguatnya posisi teori-teori normatif dan ilmu hukum. Adanya dominasi teori normatif ini menimbulkan ekses yang memunculkan hukum dalam persepsi sebagai sistem norma belaka. Dalam konteks ini, makna hukum yang utuh menjadi kabur. Pada dimensi ilmu hukum, terjadinya pereduksian hukum ke dalam perspektif normatif saja, atau meminjam istilah Satjipto Rahardjo sebagai' pemositipan hukum, telah mengakibatkan hukum tak bisa lagi tampil sebagai the truth about law ${ }^{10}$ tidak mewujud apabila hukum hanya dipersepsikan sebagai sistem normatif saja.

Apabila ditelusuri sejarahnya, perkembangan ilmu pengetahuan dipandang mengalami perkembangan sejak abad ke-6 SM yaitu ketika manusia dari peradaban Asia Kecil mulai bertanya tentang hakekat alam. Ciri utama perkembangan awal ini adalah:

1. Orientasi pengetahuan adalah obyek yang bersifat kosmologis, yaitu obyek pengetahuan yang berhubungan dengan hal-hal religius,

2. Pengembangan pengetahuan merupakan proses pendidikan yang sakral sehingga hanya melibatkan kalangan pendeta saja,

3. Perkembangan pengetahuan hanya didasarkan pada usaha untuk menggali jawaban, tidak ada perdebatan kritis di an-

${ }^{8}$ Alan Ryan. 1978. The Philosophy of Social Explanation. HIm 1-14.

${ }^{9}$ Lili Rasjidi. Op. Cit. HIm. 2.

${ }^{10} \mathrm{Gambaran}$ hukum yang utuh (the inth aboutlaw) tidaklah mungkin terlihat secara jelas apabila digunakan pendekatan normatif. Pendekatan dari aspek sosial (Sosiologi Hukum) telah terbukti memberikan gambaran hukum yang mendekati kenyataannya apabila dibandingkan hanya dengan pendekatan normatif saja. Karya Stewart Macaulay yang berjudul An Empirical View Of Contract, maupun Non-Contractual Relations in Business: A Preliminary Study dan karya Marc Galanter yang berjudul Why The "Haves" Come Out A head: Speculations On the Limit Of Legal Change adalah beberapa karya yang berhasil memotret the truth about law. 
tara para ahlinya, sebagaimana dinyatakan oleh Hawton: ${ }^{11}$

"The search started, not merely for information, but for understanding"

Inti perkembangan ilmu pengetahuan pada awal perkembangan adalah penempatan Tuhan $^{12}$ dan alam sebagai orientasi utama penjelajahan ide manusia. Ciri ini sangat mewarnai pemikiran dari Heraclitus (504 SM), Thales dan Anaximender (661-574 SM), Phytagoras (571-497) dan democrotus yang berasal dari abad pertengahan ke-5 pra Yunani. Pemikiran mereka berkisar pada cara kerja alam semesta, penciptaan, dan unsurunsur alam semesta. Perkembangan ini kemudian dilanjutkan oleh Socrates, Plato dan Aristoteles. Plato adalah orang yang mulamula menggunakan teori-teori logika dalam mencetuskan konsepsi-konsepsi pengetahuan. Sedangkan Arostoteles mengembangkan konsep rasionalitas yang berperanan penting bagi perkembangan ilmu pengetahuan di abad ke-16 dan 17.

Di samping merupakan kelanjutan dari perkembangan sebelumnya, abad ke-16 dan 17 telah menjadi puncak dari dominasi rasio dalam perkembangan ilmu pengetahuan. Tokoh-tokoh yang menonjol dalam era ini adalah Galileo, Newton dan Descartes. Dengan amat meyakinkan, Galileo menyatakan bahwa dunia dapat diselidiki dengan menggunakan rasio. Newton menghadirkan gambaran dunia yang mekanistik dengan me- kanika Newton-nya. Galileo adalah orang pertama yang menggunakan metoda eksperimental untuk menyelidiki alam yang kemudian dilanjutkan oleh Newton. Kedua orang inilah yang mengembangkan metoda eksperimental, dengan penekanan bahwa segala sesuatunya dapat diuji melalui percobaan. Hal inilah kemudian mereka sebut dengan science, yang sekaligus diyakini sebagai awal pengaburan hakikat sains itu sendiri. Proses pengaburan ini ternyata berlanjut melalui Descartes yang melakukan pemisahan antara benda dan jiwa, res cogitan dan res extensa. Masalah yang menjadi semakin fatal manakala manusia yang dijadikan obyek penelitian dianggap sebagai benda sehingga kehilangan sisi humanisnya. Akibat terburuk dari filsafat Cartesian adalah pengabaian terhadap unsur sistem kemasyarakatan, yang justru hal ini harus diperhatikan kualitas objektivitasnya untuk mencapai kebenaran. Di sinilah dapat ditemukan kelemahan filsafat Cartesian dalam aplikasi ilmu kemasyarakatan.

Bersamaan dengan berkembangnya metoda eksperimental dan filsafat Cartesian ini, berkembang pula ilmu Fisika yang berorientasi pada ruang, waktu dan benda. Ciri sains yang berkembang pada abad ke-18 dan 19 ini adalah penggunaan pendekatan yang cenderung analitis-mekanistis menggantikan pendekatan rasionalitas atau filosofis-analitis pada periode sebelumnya. Pengaruh filsafat Cartesian ini mengimbas pula ke dalam Ilmu Hu-

\section{"Hector Hawton. 1956. Philosophy for Pleasure an Adventure Ideas. Hilm. 9.}

${ }_{12}$ MenurutAugust Comte, sejarah perkembangan ilmu menuju ke kedewasaannya melalui tiga tahap yaitu teologis, metafisis dan positif. Awal perkembangan ilmu disebut sebagai tahap teologis, segala sesuatunya dipandang sebagai bernyawa dan memiliki kemauan. Tahap ini mula-mula bercorak animistik kemudian politeistik dan akhirnya menjadi monoteistik. Lihat Wilardjo. Op. Cit. Hlm. 183. 
kum, yaitu dengan lahirnya teori hukum mekanis dari aliran Hukum Positif. Aliran ini menerapkan metoda analitis-mekanis terhadap hukum. Tokoh-tokoh yang menonjol adalah David Hume, Locke, Comte, Spencer, Hans Kelsen, Jellineck, dan Paul Laband.

Peta perkembangan ilmu hukum tampak paralel dan berjalan seiring dengan perkembangan sains global. Hal ini dapat terjadi karena terdapat pemikir-pemikir yang sama dari ilmu alam dan ilmu kemasyarakatan (behavioral scince) pada awal perkembangan ilmu. Seperti Plato pada masa Yunani, Socrates ketika berbicara tentang hukum maupun ketika pytagoras berbicara mengenai keadilan sebagai suatu perimbangan alamiah. $\mathrm{Pa}$ ralelisasi orientasi penjelajahan ide manusia pada dunia hukum ini terus berlanjut pada abad setelah masehi melalui aliran Hukum Alam yang berorientasi pada universalitas (Aliran Hukum Alam (rrasional) sampai kepada aliran
Hukum Alam yang didominasi oleh rasio (Aliran Hukum Alam Rasional) melalui pemikiran dari Thomas Hobbes, Kant, Locke. Bahkan John Locke adalah tokoh yang mengawali empirisme sedangkan Kant adalah tokoh yang menengahi pertentangan antara rasionalisme dan empirisme. Pengaruh pendekatan mekanisanalitis dapat dilihat pada Kelsen ketika merumuskan teorinya, sementara pengaruh pendekatan organis dapat dilihat pada cara kalangan pragmatisme hukum dalam merumuskan teorinya. Dari perspektif sejarah sains ini tampaklah bahwa hukum adalah bagian dan terpengaruh oleh sains global. Demikian pula terjadinya pemositipan hukum dapat dilihat dAri pendekatan analitis mekanis yang dilakukan oleh pemikir-pemikir mazhab hukum positif. Secara ringkas perkembangan ilmu hukum dalam perspektif sains global dapat digambarkan dalam bagan di bawah ini sebagai berikut: ${ }^{13}$ (lihat halaman berikutnya)

\begin{tabular}{|c|c|c|c|c|c|}
\hline $\begin{array}{c}\text { Orientasi } \\
\text { Pernikiran }\end{array}$ & $\begin{array}{l}\text { Bentuk } \\
\text { Penjajahan }\end{array}$ & Metoda & Ilmu Hukum & Abad & Tokoh \\
\hline Alam-Tuhan & Universalitas & Filosofis-Instingtif & Aliran Hukum Alam Irrasional & $5-15$ & $\begin{array}{l}\text { Thomas } \\
\text { Aquinas, Hegel } \\
\text { Dante }\end{array}$ \\
\hline Pikiran & Rasionalitas & Filosofis Analitis & Aliran Hukum Alam Rasional & $16-17$ & $\begin{array}{l}\text { Hobbes, Kant, } \\
\text { Locke }\end{array}$ \\
\hline $\begin{array}{l}\text { Benda-Ruang- } \\
\text { Waktu }\end{array}$ & Fisika & Analitis Mekanis & Aliran Hukum Positif & $18-19$ & $\begin{array}{l}\text { Kelsen, Hume, } \\
\text { Austin }\end{array}$ \\
\hline Manusia & Sosial & Analitis Organis & $\begin{array}{l}\text { Utilitarianism Madzhab } \\
\text { Historis Pragmatic } \\
\text { Regal Realism }\end{array}$ & $\theta$ & $\begin{array}{l}\text { Bentham, Mill, } \\
\text { Jhering, } \\
\text { Savigny, } \\
\text { Holmes, } \\
\text { Pound, Frank }\end{array}$ \\
\hline $\begin{array}{l}\text { Kemelimpahan } \\
\text { Materi }\end{array}$ & Ekonomi & Analitis Mekanis & Pragmatis Positivis & 20 & $?$ \\
\hline
\end{tabular}

${ }^{13 B}$ Bandingkan dengan Lili Rasjidi. Op. Cit. HIm 24 dan Lihat pula Made Widnyana, et. al. Op. Cit. Hlm. 366. 
Dari bagan di atas tampak bahwa ketika penjelajahan pengetahuan berorientasi kepada alam dan Tuhan, dan ketika pendekatan atau metoda filosofis instinktif berkembang, maka dalam bidang hukum berkembanglah aliran hukum alam irrasional. Ketika orientasi penjelajahan pikiran dengan metoda filosofis analitis, berkembanglah hukum alam rasional. Pada saat orientasi penjelajahan mengarah pada benda, ruang dan waktu dengan metoda analitis-mekanis, maka berkembanglah aliran hukum positif; dan ketika orientasi penjelajahan mengarah pada perilaku manusia maka berkembanglah aliran Utilitarianian, aliran Sejarah, dan hukum Pragmatis.

Paparan di atas menggambarkan bahwa hukum sebagai bagian dari sains global, juga mendapat pengaruh yang kuat dari perkembangan sains global itu sendiri. Akibat perkembangan sains yang mengimbas pada hukum -terjadinya reduksi normatif/pemositipan hukum- merupakan gejala historis yang terjadi secara alamiah. Dialektika teoritis yang berlangsung dengan sangat ketat di dalam perkembangan ilmu hukum merupakan akibat dari kombinasi antara aplikasi metoda sains global dengan segala penyesuaiannya, dengan sifat khas dari hukum sebagai obyek ilmu hukum. Dialektika internal ini menghasilkan perbedaan pendekatan dan hasil-hasil pende- katan yang satu sama lain sangat menyerupai teori seleksi,ketatnya Popper atau teori evolusi kreatifnya Bergson. ${ }^{14}$

\section{Penutup .}

Pengaruh sains global terhadap perkembangan ilmu hukum menyebabkan ilmu hukum dalam perkembangannya mengalami reduksi normatif/pemositipan hukum. Akibatakibat yang ditimbulkan dari adanya pemositipan hukum ini adalah pertama, menguatnya kesan normatif dari hukum, kedua, menyempitnya penampakan hukum, ketiga, terputusnya hubungan hukum dengan kenyataan sosial, keempat, menyempitnya ruang kajian hukum, kelima, terarahnya hukum semata-mata untuk memenuhi kebutuhan profesional, dan keenam, terjadinya pergeseran nilai aksiologi hukum.

Akibat-akibat di atas pada hakekatnya merupakan refleksi dari mendesaknya kebutuhan terhadap suatu teori baru yang mampu membebaskan hukum dari kesan normatifnya, sehingga mampu menggambarkan hukum secara utuh (the truth about law). Oleh karena itu, kajian-kajian hukum kritis (Critical Legal Studies) perlu diberi tempat untuk berkembang dan memberikan pencerahan dalam ilmu hukum.

${ }^{14}$ Widnyana. et. al. Op. Cit. HIm. 367. 


\section{Daftar Pustaka}

Altman, Andrew. 1990. Critical Legal Studies. A Liberal Critique. New Jersey: Princeton Universty Press.

Friedmann, W. 1975. Legal Theory. London: Stevens \& Sons Ltd.

Hactor, Hawton. 1956. Philosophy for Pleasure An Adventure in ldea. Fawcett World Library.

Hart, H.L:A, 1978. The Concept of Law. Oxford at the Clarendon Press.

Hutchinson, Allan C. 1989. Critical Legal Studies. Rowman \& Littlefield Publisher, Inc.

Kuhn, Thomas. 1970. The Structure of Scientifc Revolutions. University of Chicago Press.

Kansil, CST. 1987. Hukum Antar Tata Pemerintahan. Jakarta: Erlangga.

Luhman, Niklas. 1985. A Sociological Theory of Law. London: Routledge \& Kegan Paul.

Nonet, Philip, \& Philip Selnick. 1978. Law and Society in Transition: Towrd Responsive Law. New York: Harper \& Row Publisher.

Parson, Talcott. 1977. The Evolution of Societies. New Jersey: Prentice Hall.
Peursen, Van. 1993. Susunan IImu Pengetahuan. Jakarta: Gramedia.

Poedjawijatna. 1983. Tahu dan Pengetahuan. Jakarta: Bina Aksara.

Rasjidi, Lili dan IB. Wyasa. 1993. Hukum Sebagai Sistem. Bandung: Remadja Rosda Karya.

Redman A, Deborah. 1991. Economic and The Philosophy of Science. Oxford University Press.

Ryan Alian. 1978. The Philosophy of Explanations. Oxford University Press.

Samford, Charles. 1989. The Disorder of Law. A Critique of Legal Theory. Basil Blackwell Ltd, Oxford.

Sidarta, Arif. 1996. Refleksi Tentang Hukum. Bandung: Citra Aditya Bhakti.

Suriassumantri S. Yuyun. 1982. Filsafat IImu. Jakarta: Sinar Harapan.

Taryadi, alvons. 1989. Epistimologi Pemecahan Masalah. Jakarta: Gramedia.

Wignyosoebroto, Soetandyo. 1993. Dari Hukum Kolonial Ke Hukum Nasional. Jakarta: Rajawali Press.

Wilardjo, Like. 1990. Realita dan Desiderata. Yogyakarta: Duta Wacana Press.

Widnyana, Made, et, al. 1995. Bunga Rampai

Pembangunan Hukum Indonesia. Bandung: Eresco. 